This is the version of the article accepted for publication in American Behavioral Scientist published by SAGE https://doi.org/10.1177/0002764215613380

Accepted version downloaded from SOAS Research Online: https://eprints.soas.ac.uk/31042/

\title{
IS THE RULE OF LAW AN ANTIDOTE FOR RELIGIOUS TENSION? THE PROMISE AND PERIL OF JUDICIALIZING RELIGIOUS FREEDOM
}

Ben Schonthal, Tamir Moustafa, Matthew Nelson, Shylashri Shankar

\section{American Behavioral Scientist 60:8 (2015), 966-86}

For years, a particular way of thinking about the relationship between religious strife, law, and legal processes has influenced conversations among scholars, human rights activists and policy makers. This way of thinking sees law as an antidote to religious tensions. "Rule of law," the logic goes, acts as a force of moderation and, in matters of religion, serves as a key tool for mollifying or resolving disputes.

One does not have to go far to find examples of this paradigm. In a December 2013 speech to the United Nations General Assembly, the Special Rapporteur on Freedom of Religion or Belief, Heiner Bielefeldt, celebrated the power of law to help resolve chronic patterns of religious violence and hatred. He insisted that

[a]n open constitutional framework that allows free manifestations of existing or emerging religious pluralism on the basis of equal respect for all is a sine qua non of any policy directed towards eliminating collective religious hatred by building trust through public institutions. (United Nations General Assembly 2013: 11)

According to Bielefeldt, institutions of law—above all constitutions and the courts that interpret them—serve as bulwarks against religious strife, polarization and hatred. Constitutional law, he insists, is central to resolving conflicts among religious 
groups. ${ }^{1}$ Bielefeldt's perspective finds considerable support in academic writing on constitutional law and human rights. One influential example of this can be seen in Ran Hirschl’s (2010) important book, Constitutional Theocracy, in which he writes that constitutional courts work to contain, constrain and streamline religious interests and impulses in public life such that "constitutional law and courts in virtually all such polities have become bastions of relative secularism, pragmatism, and moderation” (p. 13). A similar argument has been made in the arena of ethnic conflict where incorporating incentives that encourage moderation, cooperation and accommodation in legal and institutional arrangements (including constitutional design and amendments, the political system and electoral processes), is expected to contain, limit, channel or manage conflict (Horowitz, 1985/2000, 2002 2008; Lijphart, 2004; Reilly, 2001).

Although intuitively attractive, these understandings of law as a salve for religious strife belie the escalation of religious tensions that often accompanies the judicialization of religious disputes in much of South and Southeast Asia. A closer look at recent history in Sri Lanka, India, Malaysia, and Pakistan suggests that religion-related court cases—particularly those involving the legal defense of religious rights and religious freedoms - have not always generated the mollifying effects that scholars might predict. Rather than serving as mechanisms to soften religious boundaries and harmonize religious interests, legal processes and institutions have, in certain cases, produced a hardening of boundaries and a sharpening of antagonisms among religious communities. Law itself has participated in the intensifying of religious conflict.

This study examines how and why this intensification comes about. In what follows, we analyze several discrete instances_-from Sri Lanka, India, Malaysia, and 
Pakistan —in which law and courts have played key roles in encouraging processes of religious polarization. Our goal is not to argue that law and legal action always exacerbate religious conflict, but rather to look closely at the unintended consequences of legalizing religious conflicts and to call attention to certain ways in which legal action might deepen and sharpen the very conflicts over religion it purports to resolve. In particular, we wish to highlight four specific mechanisms through which legal procedures, structures and instruments can further polarize already existing religious conflicts. The mechanisms include the procedural requirements and choreography of litigation itself (Sri Lanka), the strategic use of legal language and court judgments by political and socioreligious groups (India), the activities of partisan activists who mobilize around litigation (Malaysia), and the exploitation of "public order” laws in contexts framed by antagonism targeting religious minorities (Pakistan). In each of the four cases examined here, law and legal institutions can be thought to intensify preexisting religious tensions.

While the countries under study share much in common—a British colonial inheritance, common law systems, personal law regimes, ethnically and religiously diverse populations, to mention just a few features-the goal of this comparison is not to present Sri Lanka, India, Malaysia, and Pakistan as jurisdictions of a specific (problematic) type. ${ }^{2}$ Rather we bring these varied case studies together in order to persuade the reader that polarization via law and legal institutions is not anomalous nor specific to any one type of context. By juxtaposing four distinct examples—each of which falls within a particular author's area of expertise-we see ourselves as taking an initial step toward broader comparative reflection on these matters. While we believe that the mechanisms of legal polarization that we examine extend to many other countries, our goal is not to have the final word, but to encourage further 
research and clear the way for new theoretical work that can help scholars and policymakers think about the counterproductive dynamics that may accompany the judicialization of disputes related to religion.

\section{Sri Lanka: Polarizing Procedures}

To say that law generates conflict might appear obvious, even mildly tautological. Among other things, law serves as a formalized system for framing disputes in public settings; a defining function of litigation involves the ordered presentation of competing claims. However, in ordering these claims and presenting them for adjudication, legal processes do not simply take social disputes as they are, in all their complexity. Rather, legal institutions produce for the court certain types of disputes that can be resolved by the court: disputes between two parties, over specific and well-circumscribed matters of law (e.g. over particular rights or duties; Shapiro, 1986). In certain cases this process of translating conflict from social-political domains into the legal domain unwittingly serves to further sharpen the interests that gave rise to conflict in the first place by requiring moderate stakeholders to align with one litigating party or another. In the case of multifaceted religious conflicts in which a range of perspectives and alignments exist, litigation may lead to the erosion of middle ground and encourage the polarization of the conflict into opposite and opposing groups.

These polarizing effects of litigation can be seen clearly in the context of popular and legal contests over religious conversion-particularly conversions to Christianity—in Sri Lanka. ${ }^{3}$ From the late 1990s until 2004, one saw in civil society and the media a vigorous debate over the proselytizing activities of evangelical Christian organizations. Many of these organizations had come to the island in recent 
decades and set up churches in rural and urban areas that were badly affected by poverty and civil war. By the late 1990s, some Sri Lankans became increasingly concerned that these groups were using "unethical" techniques to convert Buddhists, Hindus, and Catholics to evangelical Christianity. The alleged techniques included giving cash or other gifts to new converts, helping them with securing visas to live overseas, employing them within church NGOs, and extending other types of inducements to convert (Berkwitz 2008; Mahadev 2014).

In the early 2000s, a variety of religious organizations issued public statements indicating their concern about the possibility of "unethical" conversions. The Catholic Bishops Congress put out press releases expressing their concern over the "the social unrest alleged to be caused by certain activities of the fundamentalist Christian sects” (Daily News, 2003). Hindu groups, including the All-Ceylon Hindu Congress and others, condemned what they saw as the cynical conversion of waraffected Tamils by Christian groups posing as relief organizations. The Hindu author of one Tamil-language editorial from 2000 (celebrated and reprinted in the Hindu Organ) even called on Hindus to recognize the threat posed by new, foreign, extremist Christian groups, supported by foreign powers who "exploit the situation of poverty and war" to undertake a project similar to colonial-era Christians: inculcate Christianity and destroy local cultural values (intucātañam 2000, p. 26). Most prominently, a variety of Buddhist organizations rallied together to raise awareness about and combat the alleged unethical conversions among poorer urban and village populations.

At the same time, there were also religious groups who were working together to think of ways to allay concerns and propose solutions. In Colombo, several Christian groups met to consider developing a common protocol of "ethical" 
evangelizing for Sri Lanka. Similarly, representatives from popular Buddhist and Hindu organizations met to discuss the legal limits that could be applied to "forcible" conversions. In fact in early 2004, this Hindu-Buddhist group even completed a draft bill, which they submitted to the president for consideration in January. ${ }^{4}$

One could summarize the terrain of disputes over religious conversion in January 2004 as one in which a wide variety of religious groups were actively collaborating in deciding how to address allegations about unethical conversions in different ways. Some Hindu and Buddhist groups worked together in pursuing legal measures, while Catholics and certain mainline Protestants—who were empathetic to the concerns of Buddhists and Hindus-were in the process of developing their own “in-house” manuals and protocols of "ethical” conversion. ${ }^{5}$

To look at the situation 6 months later, however, one sees a pattern of radical polarization. From a situation in which a variety of religious communities were involved in interreligious and intrareligious dialogue over how best to deal with the problem of religious conversion, the issue of conversion suddenly split conservative Buddhists from all other religious communities. A major catalyst for this polarization was a large court case involving the preenactment constitutional review of a bill designed to criminalize certain types of proselytizing activities.

Between January and July 2004, during the time that Christian groups were deliberating and while the Hindu-Buddhist draft bill was being considered by the president, another draft legislation purporting to combat “forcible conversion” found its way to the floor of parliament. Called the "Prohibition of Forcible Conversion Bill,” this draft law appeared on parliament’s Order Paper in May 2004 as a Private Members’ Bill introduced by the newly elected Buddhist nationalist party known as the Jathika Hela Urumaya (JHU). Unlike the bill produced by the Hindu-Buddhist 
committee described above, the JHU's bill was not the product of extensive discussions. Instead it was an almost-verbatim copy of a conversion bill that had been introduced (and repealed) in the Indian state of Tamil Nadu. Like the Tamil Nadu bill, it rendered as a criminal offense any attempt to convert a person from on religion to another by means of physical force, financial "allurement” or "fraud.”

The introduction of the bill had the effect of pushing previously multifaceted discussions over conversion onto a path of constitutional litigation. Predictably, a variety of evangelical Christian groups opposed the bill and, turning to a form of legal action, invoked constitutional procedures of preenactment judicial review, requesting the Supreme Court to rule that the bill violated fundamental rights to freedom of religion. ${ }^{6}$ Equally predictably, the more nationalistically inclined Buddhist groups, led by the JHU, rallied behind the bill and intervened against the judicial-review petitions.

What is notable is that the Catholic Bishops, Hindu groups, and more centrist Buddhists — all of whom had previously voiced sympathetic concern for popular anxieties about "unethical" conversions - were now in a bind. With the arrival of a litigious framework, they found themselves pulled towards the inflexible position of taking one side (that of the nationalist Buddhist JHU and its bill) or the other side (that of opponents calling for preenactment judicial review to prevent legal limitations on conversion) in response to an issue that, for them, was much more complex. Those who opposed legal limits on conversion, even if they were deeply concerned about conversion practices, felt compelled to oppose such a harsh and inflexible law. At the same time, those who favored a legal solution felt that, even if they did not approve of the terms of this particular bill, they should at least intervene on its behalf to ensure that the court would not rule unconstitutional the very idea of a legal limitation on 
religious conversion. The result was that the same Hindu and Christian individuals and groups that had been involved with designing other creative types of solutions to the "conversion problem” petitioned against the bill, while conservative Buddhist groups that had previously worked alongside Hindu organizations to draft their own bill joined the JHU in their legal defense.

In interviews conducted in 2008 and 2009, representatives from all sides indicated how unsatisfactory and frustrating this shakedown was. One Buddhist member of the Buddhist-Hindu working committee characterized the experience of committee members as follows:

[S]ome people felt, what is the point in this [JHU Conversion] bill, it is bloody useless we will not have this bill. But most of the people felt, 'well half a loaf is better then none, let us at least have this.... ${ }^{7}$

Similar appraisals were made by members of Christian and Hindu groups that were interviewed, many of whom referred to the fact that, with the turn towards litigiousness, all other attempts at dealing with the issue of unethical conversion (either through interreligious committees, or civil society projects or intra-Christian reform initiatives) abruptly halted.

This is not to say that there were no attempts to communicate the complexity of the issues at play; some petitioners did. Yet these suggestions of complexity were ultimately drowned out or obscured in the gross logic of a more powerful litigiousness, which presented the debate - to both the court and, significantly, to the public-at-large who followed these proceedings with interest in newspapers and on TV_as an agonistic battle between two parties: opponents and supporters of the bill, or, even more starkly, as opponents or supporters of formal, state-based, legal limits on "unethical” conversion. That is, the logic, choreography and procedural requirements of constitutional review—which remained "hard wired" 8 to present the 
debate as a contest between two opposing parties, petitioners and intervening petitioners—-worked to dilute and cover over the many innovative solutions that had been proposed previously by groups and alliances representing a variety of religious organizations and denominations.

The above anecdote serves as a powerful illustration of the ways in which the choreography and requirements of litigation may polarize religious interests and undermine the possibility for middle-ground compromises. This is especially true in cases where (as in the 2004 conversion bill) there are a variety of interested parties and stakeholders, and where legal action is initiated by groups on one end of the ideological spectrum and opposed by those on the other. In the Sri Lankan case, constitutional frameworks and the protocols and procedures they imposed on articulating and managing conflict worked to transform what were previously multireligious and interreligious groups into a stark Buddhist versus others binary. In addition, the many possibilities for realignment and border crossing that presented themselves prior to the JHU bill case seemed to disappear. Once processed through the authorized mechanics of constitutional litigation, Sri Lankans found it difficult to reclaim or recover the terms and creativity of a more fluid prelitigation state.

\section{India: Polarizing Judgments}

Like Sri Lanka, India has also been a site for conflict and controversy over religious conversion. Here, too, constitutional law and judgments on religious conversions have polarized religious groups. In particular, they have provided opportunities for socioreligious groups, particularly the Hindu Right, to polarize public discourse and deepen discord among India's religious communities. ${ }^{9}$ 
To see how this works, one must go back to 1978, when a Christian missionary named Reverend Stainislaus challenged the Madhya Pradesh Freedom of Religion Act (passed in 1968) in the Madhya Pradesh High Court. The Act prohibited conversion by force, fraud, or inducement (a very similar formula to the Sri Lankan bill described above) and prescribed 1 year's imprisonment and a fine for those convicted. Stanislaus objected to the Act on the grounds that the definition of inducement was overly broad. Losing the case in the High Court, Stainislaus appealed to the Supreme Court, where the case was heard with another case from Orissa, relating to a similar law regarding conversion. ${ }^{10}$ In its verdict, the Supreme Court of India upheld both acts. The Chief Justice, writing for the court, insisted that there was “no fundamental right to convert another person to one’s own religion” because such a right "would impinge on the freedom of conscience guaranteed to all citizens of the country alike” (Stainislaus v. State of Madhya Pradesh, 19772 SCR 611).

Interpreted as a victory for Hindus (vis-à-vis Christian missionaries), this verdict emboldened the Hindu Right in India, prompting Hindu nationalists to introduce a new federal "Freedom of Religion Bill" in the Indian Parliament in December 1978. The Bill (modeled on the 1968 Act in Madhya Pradesh) sought to prohibit conversion from one religion to another by the use of force or inducement or by fraudulent means, and cited the Stainislaus judgment as legitimizing the Bill. ${ }^{11}$ This Bill was backed by the Prime Minister (Morarji Desai) of the ruling coalition, who portrayed it as a way to give tribal groups the "protection of the state" from conversion by missionaries. Although the Bill did not pass (because the Prime Minister subsequently withdrew his support after agitation by Christian groups), this high profile legislative attempt stimulated the introduction of several state-level 
anticonversion bills in the state legislatures of Gujarat, Chattisgarh, and Himachal Pradesh. ${ }^{12}$ The court's disinclination to strike down such bills influenced the Tamil Nadu government to enact an anticonversion Ordinance in 2005 (mentioned in the case of Sri Lanka, above), which it subsequently withdrew for political reasons. Challenges to the other bills are currently pending in India's courts.

The Stainislaus verdict and its aftermath pose two questions for scholars: (a) Is the Supreme Court of India biased towards Hindus and against the proselytizing religions of Islam and Christianity and (b) even if it is, what explains the way that the judgment was politicized by the Hindu Right? ${ }^{13}$

In surveying conversion-related cases in India's higher judiciary, one can clearly observe a trend towards limiting conversion activities. The higher judiciary in India has favoured an anticonversion stance, not because judges are biased, but because of decisions made in the constitution to limit the access to social justice to, among others, the bottom-most groups within Hinduism. ${ }^{14}$ Caste, a hierarchical system that impacts significantly Hindus' social status, occupational and economic roles, is central to Hinduism, which accounts for approximately 80.5\% (2001 Census) of India's population. In addition, 13.4\% are Muslims, and 2\% are Christians (2001 Census). Most disadvantaged in the caste system are the dalits, whom Indian legal discourse refers to as “scheduled castes” (SCs, approximately $16.6 \%$ of India’s population according to the 2011 Census). Dalits are often derogatorily referred to as "untouchables" and have traditionally suffered discrimination and violence at the hands of the upper castes, and continue to do so even today particularly in rural India. Most conversions in independent India occur among dalits/SCs and "scheduled tribes" (indigenous peoples who too have suffered such discrimination) who want to 
improve their low social standing by converting to Islam and Christianity, which promise "equality" to their congregants.

The framers of the Indian Constitution had a foundational commitment to social justice for these discriminated groups, and allowed only SCs and scheduled tribes to qualify for affirmative action benefits. These benefits include quotas reserved in government jobs, political constituencies, and educational institutions. However, the initial legal definition of an SC as a Hindu or a Sikh, limited the range of beneficiaries to the disadvantaged groups within Hinduism. This decision has meant that the constitution (and India's lower laws that conform to it) inadvertently installed barriers to conversion from Hinduism. It is this constitutional linking of entrenched social disadvantage with Hinduism that explains the apparent anticonversion bias of the courts. By curtailing the ability of an SC convert to access affirmative action benefits, courts have discouraged conversions from Hinduism, but also indirectly encouraged reconversions to Hinduism, thereby creating discord with the proselytizing religions (namely, Christianity and Islam), and deepening, rather than modulating, religious polarization.

An analysis of 80 religious conversion cases in the High Courts and the Supreme Court reveals a jurisprudential tilt towards facilitating conversion to Hinduism and obstructing conversion away from Hinduism. Of the 80 cases, $42 \%$ dealt with affirmative action benefits, 38\% with personal law disputes, and 15\% pertained to propagation. ${ }^{15}$ Reconversions to Hinduism (36\%) and conversions to Islam (23\%) and Christianity (28\%) were among the main issues tackled by the courts in these cases. In over half of the cases dealing with affirmative action, SC converts to Islam and Christianity were stripped of their welfare benefits, though several judgments recognized that even after conversion caste sticks to the convert. But on 
reconversion to Hinduism, the Court, on grounds that affirmative action was a group right, allowed the SC person to regain the welfare privileges as long as he or she could prove that the caste had accepted him into its fold (S. Anbalangan v. B. Devarajan, 1984 AIR 411). Scheduled tribe converts on the other hand, were more likely to receive a favourable ruling. They were allowed to retain their benefits on grounds that "a member of a Tribe despite his change in the religion may remain a member of the Tribe if he continues to follow the tribal traits and customs" (State of Kerala and Anr v. Chandramohanan [2004) 3 SCC 429).

In reviewing these cases, one can see that the Indian constitution and its interpreters, the judiciary, in their pursuit of one legal goal (social justice) have encouraged a particular interpretation of religious freedom which, in its application to affirmative action, favors Hinduism over and against Christianity and Islam. ${ }^{16}$ The bias of the law towards Hindu SCs curtailed the freedom of proselytizing religions to convert, created interreligious discord, buoyed Hindu majoritarianism, and angered influential members of minority religions.

Let us focus on the use of legal judgments by Hindu nationalists, who have long opposed proselytizing. Their guiding ideology, known as Hindutva, or Hinduness, was defined by V.D. Sarvarkar in the 1920s as “embracing all the departments of thought and activity of the whole Being of our Hindu race.” For Savarkar, who was an atheist, Hindus were a "race” who by definition followed a particular religion. Relatedly, Hindutva was a means for promoting the superiority of the Hindu race. Sarvarkar’s ideological heir, M.S. Golwalkar, felt that the exodus of Hindus to other religions would be "dangerous to the security of the nation and the country." 17 Given the inability of the caste structure to deliver equality and dignity to the SCs (12\% of the population) within Hinduism, and the fact that the court has 
allowed scheduled tribes (who are not within the caste structure) to retain the benefits of affirmative action after conversion, it is not surprising that the Hindu Right has backed anticonversion bills as being the most effective route to stopping the exodus.

In the wake of the Stainislaus’ decision, India's courts have given Hindu nationalists new ways to express and legitimize their long-standing opposition to conversion. Part of the blame also lies with the ambiguity in the Indian Constitution, in particular, its difficulty in classifying Hinduism, which Constituent framers variously viewed as a religion, culture, and a way of life. ${ }^{18}$ This perhaps-unavoidable ambiguity has contributed to judgments that have blurred the line between religion, ideology, culture, and politics. This was most notably highlighted in a set of judgments on the Bharatiya Janata Party's use of "Hindutva” in election speeches, and provided the proponents of the Hindu Right with “a judicial imprimatur” to use Hindutva in the public and political arenas. ${ }^{19}$

It is unsurprising, then, that the ideologues of the Rashtriya Swayamsevak Sangh (RSS) and other organizations of the Hindu Right had a positive image of the court's judgments on proselytization. In their view, the court tried to "minimize the harmful impact of the constitution" and "balanced" the needs of (the predominantly Hindu) society by handing down judgments against conversion and “upholding Hinduism or Hindutva as part of the national character rather than confining it to a religion on par with Islam and Christianity”. ${ }^{20}$ It is also unsurprising that, in December 2014, RSS members led a mass conversion drive in which 350 Muslims in Agra were "returned home” to Hinduism. This sparked an explosive debate in Parliament and a walkout by the opposition, who called on the government to protect the constitutional rights of religious minorities. What this episode shows is an escalation of "Hindu proselytization" aimed at creating insecurity for the 
proselytizing religions, forcing Christian and Muslim groups to demand the state's intervention and ironically perhaps even an anti-conversion law. The strategy of the Hindu Right is clear from their comment that the Modi government was "free to bring a law to ban conversions by inducement and fraud, including Agra conversions” (Gurumurthy, 2014).

The complex story of conversion laws in India shows how the language of religious freedom and the authority of the courts can work to add further fuel to religious nationalism and give further legitimation to patterns of minority exclusion. In these cases, the formally neutral rubrics of religious freedom and religious rights have covered over very real social justice issues within the Hindu community itself: concerns over out-conversion from Hinduism have provided a convenient cover for ignoring the continuing harmful effects of caste. If Indian law has been revolutionary in its ambitions for religious harmony, freedom, and reform, it has been equally culpable in the stalling and inhibiting of each. Courts, by hardening boundaries and sharpening antagonisms among religious communities, will have to share the guilt.

\section{Malaysia: Polarizing Activists}

Courts also stand at the center of heated debates concerning religious freedom in Malaysia. Conventional accounts trace these tensions to the rise of the dakwah (religious revival) movement, which has been the most dynamic social and political trend since the late 1970s. According to this understanding, legal controversies around religious freedom are the result of a standoff originating outside the courts, between an ascendant religious movement and a liberal constitutional order. Framed this way, the question that naturally follows is whether the courts have the ability and resolve to uphold religious liberty, or if they will succumb to popular political pressure. ${ }^{21}$ This 
understanding of the root problem (religious revival), what is at stake (liberty), and the institutional mechanisms to defend those values (law and courts) comes effortlessly because it matches our taken-for-granted understanding of the role of the law and courts in defending fundamental liberties and sustaining secularism.

But this functional understanding of judicial process precludes deeper insight into how and why religious liberty cases continually crop up in the Malaysian courts. A first clue that we need to search for deeper meaning in the Malaysian context is the fact that appeals to religious liberty are invoked by a variety of actors, each working at cross-purposes. Claims to religious liberty are made by religious minority groups (Buddhist, Christian, Hindu, Sikh, Taoist, and heterodox Muslims) vis-à-vis the Muslim majority. But spokespersons for the Muslim majority also deploy "rights talk” vis-à-vis religious minority groups. And claims to religious freedom are not only voiced across communal lines; they are also heard within religious communities, as individuals assert the right to religious liberty for their own persons, whereas spokespersons of religious communities invoke religious liberty in their claim to defend collective norms from state interference.

These dynamics were at work in the most well-known Malaysian court case, Lina Joy v. Religious Council of the Federal Territories, which lasted nearly a decade and became a public spectacle at home and abroad. ${ }^{22}$ The case concerned a woman who sought state recognition of her religious conversion from Islam to Christianity. In litigating Joy’s right to religious freedom, her attorneys challenged the personal status laws in force in the Federal Territories, which provided no viable avenue for the state to recognize conversion out of Islam. Joy’s attorneys argued that the laws violated her right to religious freedom, a right enshrined in Article 11 of the Malaysian Constitution, which states (in part) that "Every person has the right to profess and 
practice his religion....” But Joy’s opponents invoked another clause from the same article, which states that "Every religious group has the right...to manage its own religious affairs...” This second set of attorneys also claimed the right to religious freedom, but they argued that Article 11 was meant to safeguard the ability of religious communities to craft their own rules and regulations (including rules of entry and exit) free from outside interference. It is striking that protagonists on both sides of the controversy invoked religious freedom, and that both sides called upon the state to secure these alternate visions.

While the legal battle raged on for over a decade in the Malaysian courts of law, an equally significant battle emerged in the court of public opinion. Competing groups of politicians, media outlets, and civil society groups shaped public discourse along two competing frames. Liberal rights groups formed a coalition named "Article 11 ” after the article of the Federal Constitution guaranteeing freedom of religion. The coalition included prominent human rights organizations, including the All Women's Action Society, the Bar Council of Malaysia, the National Human Rights Society (HAKAM), the Malaysian Civil Liberties Society, Sisters in Islam, Suara Rakyat Malaysia (SUARAM), and the Women’s Aid Organization. The Article 11 Coalition also included the Malaysian Consultative Council of Buddhism, Christianity, Hinduism, Sikhism and Taoism (MCCBCHST), an umbrella organization representing the concerns of non-Muslim communities in Malaysia. The objective of the Article 11 coalition was to focus public attention on the erosion of individual rights and to "ensure that Malaysia does not become a theocratic state." 23 The coalition produced a website, short documentary videos, and recorded roundtables on the threat posed by Islamic law. They went on to organize a series of public forums across Malaysia. 
Parallel to this mobilization, a broad array of over 50 conservative Muslim NGOs united in a second coalition calling itself Muslim Organizations for the Defense of Islam (Pertubuhan-Pertubuhan Pembela Islam), or Defenders (PEMBELA) for short. PEMBELA's founding statement explained that the immediate motivation for organizing was the ongoing court cases which, in their view, challenged "the position of Islam in the Constitution and the legal system of this country.”24 PEMBELA organized dozens of public forums and flooded the Malay language press with hundreds of articles and opinion pieces on the need to defend the autonomy of the shariah courts from outside interference. ${ }^{25}$

Lina Joy’s case remained unknown to the Malaysian public until it was brought into the media spotlight by these liberal and conservative activists beginning in 2002. ${ }^{26}$ Taken from the court of law and deployed in the court of public opinion, these legal controversies assumed a different character. Political entrepreneurs, particularly those on the conservative side of the divide, did not stress the technical details of the Lina Joy case and other similar cases. Quite the opposite, they mobilized around the cases to advance more expansive rights claims and narratives of injury. Complex legal dilemmas were transformed into compelling narratives of injustice and redeployed in the public sphere. The cases gave new energy and focus to variouslysituated civil society groups, catalyzed the formation of entirely new NGOs, and provided a focal point for political mobilization outside of the courts.

Two factors facilitated the efforts of activists to translate court rulings into compelling narratives of injustice. First, court rulings and the logics that supported them were not fully legible to those without legal training. Judicial decisions are “technical accounts” as opposed to “stories” (Tilly 2006) and, as such, they are not easily accessible to a lay audience. The technical nature of court rulings affords an 
opportunity for political entrepreneurs to recast specialized and specific matters along broader stylized and emotive frames, presenting polarized narratives of injustice for public consumption. A second factor that enabled political actors to effectively convey strikingly different messages was media segmentation along ethnolinguistic lines. Although English is the common language for most educated and urbanized Malaysians, the vernacular press is divided between Chinese, Tamil, and Malay language media, each of which carried strikingly divergent coverage of the cases that mapped on to the polarizing narratives advanced by liberal and Islamist NGOs.

The political spectacle accompanying these cases exacerbated the dilemmas that attorneys, judges, and everyday citizens encountered in their efforts to maneuver through the Malaysian legal system. In the past, attorneys had found pragmatic ways of helping Malaysians change their official legal status, in spite of lacunas in the law. Malaysians had been able to secure state recognition of conversion by affirming a statutory declaration before a commissioner of oaths and registering a new name in the civil court registry through a deed poll. ${ }^{27}$ With these two documents, an individual could then secure a new identity card reflecting the name change, which signified one’s new, non-Muslim status. For most purposes, including marriage, one could then go on with life as one wished (Ahmad 2005). In other words, workable solutions were available for individuals and couples attempting to negotiate their way between the two personal status regimes. ${ }^{28}$

But once Lina Joy and other cases became the object of intense public debate, intense pressures engulfed both the shariah and the civil courts. This politicized environment made it difficult even for sympathetic shariah court judges to facilitate state recognition of conversion out of Islam. Likewise, intense political pressure made it difficult for civil court judges to intervene when fundamental liberties were in 
jeopardy. Ironically, the tools and institutions that we instinctively turn to for justice-law and courts_-had become a principal source of political tension in Malaysia. Instead of resolving legal questions, the court system produced legal controversies anew. Rather than simply arbitrating between contending parties, court rulings exacerbated ideological cleavages. And, instead of assuaging uncertainties, courts repeatedly instilled a tremendous degree of uncertainty, indeterminacy, and anxiety around the meaning and content of "religious freedom.”

\section{Pakistan: Polarizing Protests}

When Pakistan was created in 1947, constructions of the Muslim 'nation' incorporated both Sunni Muslims as well as Shi'a and Ahmadi figures like Mohammad Ali Jinnah (the Father of the Nation) and Foreign Minister Zafarullah Khan. Religious minorities often crossed over into a broadly secular mainstream; sectarian boundaries were blurred to make space for new political alliances; and doctrinal boundaries were enlarged to facilitate the process of nation-building. ${ }^{29}$

Over time, however, this framework changed as minority groups like the Ahmadis came to be excluded. This exclusion was often legitimized by means of broad legal rubrics that remain absolutely central to most liberal constitutional regimes - above all, the view that religious freedom is protected "subject to public order.” It was, in many ways, via the manipulation of these legal rubrics that heterodox groups like the Ahmadis came to be excluded. At the level of religious selfidentification, the Ahmadis did not actively convert away from Islam; their selfidentification as Muslims was simply reinterpreted as an insult to other Muslims and, as such, a religious "provocation” threatening public order. This reference to the legal 
notion of public order was, in turn, used to justify the derogation of their fundamental rights.

Pakistan’s early constitutional drafters sought to balance a concern for legally defensible fundamental rights (including religious freedom) with a preambular nod to the sovereignty of God (“delegated to the state through its people”). ${ }^{30}$ This constitution-writing process was notable insofar as it involved lay Muslims seeking to marginalise the influence of Muslim clerics who claimed an exclusive power to ascertain the will of God (and, thus, to interpret the meaning of God's sovereignty). In effect, Pakistan's lay leaders sought to manage the influence of clerical views in order to protect more inclusive ideas about the religious parameters of the nation.

Even as the constitution-drafting process was still underway, however, clerics and conservative religious activists sought to reverse their marginalisation. Beginning in 1952, they set aside the technical niceties of constitutional drafting and sought to define the boundaries of the Muslim community on the streets. Rejecting the marginalisation of their distinctive theological perspective, for instance, they attacked Pakistan’s heterodox Ahmadi community as “apostates” in a series of urban riots seeking to shore up their own position in defining the parameters of the nation. In doing so, however, they were seen by state officials as vigilantes rebelling against state authority.

As rioters, they were demonized by the courts. And, in one rather prominent case (namely, that of Syed Abul ala Maududi), they were tried and jailed for “treason.” During the 1950s, in fact, the courts followed Hirschl in prioritising the fundamental rights of the Ahmadis against a coalition of religious activists who believed that constitutional references to "the sovereignty of God" meant that the 
boundaries of the nation should be subject to their own expertise in defining "the limits prescribed by [Allah]” (Muhammad \& Kayani, 1954).

This pattern of polarization between Pakistani clerics (stressing the ulema's privileged position in defining "the limits prescribed by [Allah]”) and local Ahmadis (stressing the primacy of each citizen's fundamental rights) was further reinforced during the late 1960s in a case known as Abdul Karim Shorish Kashmiri v. West Pakistan (1969). In this case, the courts declared that the government was permitted to close down an anti-Ahmadi publication owing to a constitutional article stating that religious liberties were protected “subject to public order.” In effect, the court held that, in describing the Ahmadis as apostates, the publication in question encouraged vigilante action. The court simply used the language of "public order" to reinforce the line protecting Ahmadis from any limits unilaterally imposed by conservative Muslims.

After 1973, however, Pakistan’s constitution was rewritten. The drafting process retained most of the existing language regarding the sovereignty of God, the role of the state and its elected representatives, the delineation of fundamental rights, and "the limits prescribed by [Allah]”. But, just 1 year after Pakistan's new constitution was unveiled, religious conservatives proposed a specific constitutional amendment prohibiting the country's Ahmadis from being legally recognised as "Muslims."

Initially, Prime Minister Zulfiqar Ali Bhutto was reluctant to table this exclusionary amendment. But, when the same religious leaders threatened mass protests - partly owing to their lack of power in the Constituent Assembly after an unprecedented but still relatively poor showing in the 1970 elections (winning just 18 out of 138 seats in West Pakistan)—Bhutto reconsidered. After a string of skirmishes following what was known as “The Rabwah Incident,” Bhutto formed a special 
parliamentary committee (including a disproportionate number of clerics) to examine the legal status of the Ahmadis. "In making this decision,” writes Ali Usman Qasmi (2014), Bhutto hoped that "parliamentary procedures would slow down the course of the agitations” (p. 177).

The constitutional amendment crafted by this special parliamentary committee enjoyed considerable popular support; in fact, it received the unanimous support of the legislature in September 1974. In effect, clerical voices seized the moment to reverse a long-standing pattern of legal marginalisation—not only during Pakistan’s early constitutional debates but also in a series of decisions issued by the superior courts. Combining active participation in a small parliamentary committee with threats of mass mobilization, they intervened to reshape the constitution itself.

Pakistan's second constitutional amendment (withdrawing state recognition of the Ahmadis as "Muslims") was challenged just a few years later as a violation of the Ahmadis’ basic rights. However, in the case that followed (Abdur Rahman Mobashir v. Amir Ali Shah, 1978), Pakistan's conservative religious forces were frustrated once again. Rearticulating its earlier position, the Supreme Court held that, although the Ahmadis' religious identity had been legally redefined (meaning that, constitutionally, they were no longer seen by the state as “Muslims”), their remaining constitutional rights were still in place (Saeed, 2011). In effect, the court held that peaceful religious practices, including Ahmadi practices, were constitutionally protected from state interference because they did not interfere with the religious practices of others.

This case (Mobashir) quickly generated a political response of its own. In particular, it prompted yet another group of religious conservatives to threaten mass protests if their demands for constraints on peaceful Ahmadi practices were not met. These threats of mass mobilization and protest dovetailed with the populist 
Islamization agenda initiated by Prime Minister Bhutto and then expanded by his military successor, General Zia-ul-Haq, prompting specific amendments in the Pakistan Penal Code between 1984 and 1986. Above all, these amendments noted that any Ahmadi who referenced "Muslim" terms and practices—for example, describing his or her place of worship as a masjid (mosque)—was guilty of causing grave religious offense and, thus, at least potentially, disturbing public order. In fact this new round of legal reforms growing out of protests inspired by Mobashir turned the formal legal tables upside down. It was no longer religious vigilantes who were seen by the law as disturbing public order; it was, rather, the Ahmadis themselves who were seen as disturbing public order as heretical or blasphemous provocateurs. In the wake of Mobashir and the protests it engendered, Zia's amendments in the Pakistan Penal Code gave the intimidating practices associated with moral vigilantism a certain measure of formal legal cover.

The constitutionality of these new alterations in the Pakistan Penal Code was challenged, first in the Federal Shariat Court (Mujibur Rehman v. Federal Government, 1985) and then in Pakistan’s Supreme Court (Zaheeruddin v. the State, 1993). But, this time, the court revised its approach. This time the court held that the legislature's promulgation of regulatory measures (stipulating the boundaries of peaceful religious practice) was unfettered. In effect, hewing closely to a pattern of Supreme Court jurisprudence privileging the power of parliament-as-a-whole in matters of religion (Nelson, 2015) — a point that also figured prominently in the debates that led to Pakistan's second constitutional amendment- the Court did not intervene to reduce existing levels of legal uncertainty regarding the protection of fundamental rights; it actually introduced a measure of uncertainty by highlighting the power of each elected legislature to "regulate" such rights and, therein, to determine 
which types of peaceful religious practice, under which conditions, might be seen as a “threat to public order” deserving, not protection, but prohibition.

In Pakistan, the formal legal treatment of those using street power to exclude ostensibly heretical citizens changed over time. Initially, they were prosecuted as vigilantes; but, later on, their actions were protected as a response to religious provocation. Instead of functioning as a check on religious strife, court-based references to "public order" became an instrument through which the perpetrators of street-level violence got their exclusionary objectives legally authorized by the state. In effect, legal imperatives to protect public order were used to entrench and deepen divisions between mainstream Muslims and Ahmadis—divisions that intensified over time. Before 1986, religious vigilantes were prosecuted as a threat to public order. But, thereafter, violent forms of public protest have emerged as a tried-and-tested means for restricting the boundaries of Pakistan's Muslim community within the terms of the law.

\section{Conclusion}

In these vignettes from Sri Lanka, India, Malaysia, and Pakistan, we provide an alternative account of the link between legal processes and religious tensions, one that considers closely the roles played by constitutional law and legal procedure in perpetuating and deepening conflict. While legal institutions did not create these conflicts from scratch or act alone in aggravating them, they did play a role in sustaining and/or sharpening these conflicts. These four cases show how law can work in tandem with political and social forces to amplify, deepen, naturalize, entrench, or further polarize already existing religious tensions. More precisely, these cases call attention to four distinct ways in which law and legal procedures can and do 
increase polarization among groups in South and Southeast Asia: via the procedural requirements of litigation, via the strategic use of legal language and court judgments by socioreligious groups, via the popular representation of court decisions by activists and media; and via the exploitation of "public order" laws in contexts framed by antagonism targeting religious minorities. Moreover, a more extended analysis would likely reveal that multiple modes of polarization were at play in each of the four cases.

Among other things, these examples stand as counternarratives to the more standard accounts of conversion in Sri Lanka, Hindutva in India, religious politics in Malaysia, or Ahmadi exclusion in Pakistan. In these standard accounts, law's role is interpreted in the idiom of failure: in Sri Lanka, courts failed to definitively resolve grassroots disputes over conversion; in India, majoritarian bias crept into and subverted constitutional jurisprudence; in Malaysia, poorly conceived legal principles heaped impossible burdens on non-Muslims; in Pakistan, courts and constitutions failed to advance ideals of liberal inclusiveness. In these standard narratives, polarization, conflict, and violence are thought to result not from law’s influence, but from an absence of law's influence.

In each of these cases, one could place the blame with legal draftspersons, constituent assemblies, or higher court judges. One could argue that had elites in Sri Lanka, India, Malaysia, and Pakistan created more sensible laws and legal institutions or exercised more independence in higher court judgments, legal procedures might have successfully resolved rather than augmented the tensions in question. Indeed, this has been an influential way of analysing the cases described above. However, by jumping to conclusions about the would-be effectiveness of a more perfectly designed law (to read these histories as narratives about "bad law” or "botched law”), one 
prematurely exculpates law; it ignores the roles that the real-world legal institutions and mechanisms do play in deepening religious strife. That is, to read these accounts as stories of (ideal) law's absence rather than as stories of (actual) law's presence, is to approach social, legal, and political history in a millenarian mode: waiting for the saving power of a perfect law to set things right. The majoritarian slant of Indian courts or the trumping power of state-based declarations regarding "public order" in Pakistan's courts may well be deviations from an ideal designed in the philosophical “clean room” of philosophical liberalism, but they are certainly not aberrations as the law is lived and practiced in South and Southeast Asia.

In offering these revaluations and alternative narrations, we strive to normalize law's role in sustaining, reshaping, and advancing social strife by shining a light on some of the polarizing mechanisms of law. As seen in Sri Lanka, the protocols of litigation may render more binary and rigid what are often more fluid and flexible religious communities and boundaries. As seen in India, the language and opinions of court decisions cannot be fixed within a liberal politics; they may also be used as political slogans to justify exclusionary politics. As seen in Malaysia, court cases may serve as focal points for political activists to advance starkly different notions of rights, such that judicial decisions undergo significant discursive polarization in "the court of public opinion.” And, as seen in Pakistan, the powers of apex courts to authorize or deauthorize particular notions of public order may merge with streetlevel politics to validate highly polarizing claims about the boundaries of the Muslim community. Indeed, the law’s attempted monopolization of religious boundary making in the wake of the 1973 Constitution may have done more to foster religious conflicts than a less centralized and rigid approach. 
To see law's polarizing potential is not to dismiss law out-of-hand or to call for scholars to abandon the dominant form of institutional organization and dispute resolution in most parts of the world. It is also not to claim that law polarizes (or polarizes equally) in all places and times. We have tried to specify particular situations under which polarization took place and, then, to account for particular features and circumstances that made those polarizing effects more problematic or pronounced. In pointing to these dynamics, we hope to encourage scholars and policy-makers to take seriously both the benefits and the unintended consequences of judicializing disputes over religion, and in doing so to introduce a new spirit of creativity, modesty, and humility about the ameliorative powers of law. This may lead us back to a reaffirmation of liberal constitutionalism——a second naïveté,” as Paul Ricouer would have it—but from a place of scrupulous pragmatism and clear-eyed realism about both the losses and the gains associated with the rule of law.

\section{References}

Adcock, C. (2013) The Limits of Tolerance: Indian Secularism and the Politics of Religious Freedom. Oxford, England: University Press.

Ahmad, S. (2005). "Islam in Malaysia: Constitutional and Human Rights Perspectives" Muslim World Journal of Human Rights 2:1.

Berkwitz, S. C. (2008). "Religious Conflict and the Politics of Conversion in Sri Lanka” in R.I.J. Hacked (Ed.), Proselytization Revisited : Rights Talk, Free Markets and Culture Wars. London, England: Equinox.

BJP Resolutions - Political 1980-99, Pub No. E6/2000 p. 304.

Cossman, B. \& Kapur, R. (1996). 'Secularism: Benchmarked by the Hindu Right,' Economic and Political Weekly 31, 2613-2630

Cossman, B. \& Kapur, R. (2001). Secularism's Last Sigh? Hindutva and the (Mis) Rule of Law. Oxford, England: Oxford University Press.

Daily News (2003). “No Links with Fundamentalist Sects, Say Catholic Bishops” Dec 19.

Hirschl, R. (2010). Constitutional theocracy. Cambridge, MA: Harvard University Press. 
Horowitz, D.L., (2000 [1985]). Ethnic Groups in Conflict, 2nd edn. Berkeley, CA: University of California Press.

Horowitz, D.L. (2002). “Constitutional Design: Proposals Versus Processes” in A. Reynolds (Ed.), The Architecture of Democracy: Constitutional Design, Conflict Management, and Democracy. Oxford, England: Oxford University Press (pp. 15-36).

Horowitz, D.L. (2008). “Conciliatory Institutions and Constitutional Processes in Postconflict States, William \& Mary Law Review 49, 1213-1248

intucātanam (2000). “Matamārrrattil îtupațuvōr Manitanēyamarravarkal” [Those who engage in Conversion Have no Compassion for Humanity], November 12, page 26.

India Today. (1996). Voices, January 15, 1996. [ http://www.rediff.com/chat/pravchat.htm; accessed May 1, 2015]

Lijphart, A. (2004). 'Constitutional Design for Divided Societies.” Journal of Democracy 15:2, 96-109.

Liow, J.C. (2009). Piety and Politics: Islamism in Contemporary Malaysia. Oxford, England: Oxford University Press.

Mahadev, N. (2014). “Conversion and Anti-conversion in Contemporary Sri Lanka: Pentecostal Christian Evangelism and Theravada Buddhist Views on the Ethics of Religious Attraction” in J. Finucane and M. Feener (Eds.) Proselytizing and the Limits of Religious Pluralism in Contemporary Asia (pp. 211-236) New York, NY: Springer.

Malkani, K.R. \& J.P. Mathur (1997). BJS to BJP: ‘Two Essays on Ideology in Action', BJP publication No. E/6/97, 1997.

Moustafa, T. (2013). "Liberal rights versus Islamic law? The Construction of a Binary in Malaysian Politics.” Law \& Society Review, 47, 771-802.

Moustafa, T. (2014). “The politics of religious freedom in Malaysia.” Maryland Journal of International Law 29, 468-491.

Muhammad, M., \& Kayani, M. R. (1954). Report of the Court of Enquiry Constituted under Punjab Act II of 1954 to Enquire into the Punjab Disturbances of 1953. Lahore, Pakistan: Government Printing.

Nelson, M. (2015). 'Islamic Law in an Islamic Republic: What Role for Parliament?’ in A. Bali and H. Lerner (Eds.), Constitution-Writing, Religion, and Democracy Cambridge, England: Cambridge University Press.

Nussbaum, M. C. (1999). The Clash Within: Democracy, Religious Violence and India's Future. Cambridge, MA: Harvard University Press.

Qasmi, A.U. (2014). The Ahmadis and the Politics of Religious Exclusion in Pakistan London, England: Anthem.

Reilly, B. (2001). Democracy in Divided Societies: Electoral Engineering for Conflict Management. Cambridge, England: Cambridge University Press. 
Schonthal, B. (2014). "Constitutionalizing Religion: The Pyrrhic Success of Religious Rights in Postcolonial Sri Lanka." Journal of Law and Religion 29, no. 3, 470-490.

Saeed, S. 'The Nation and Its Heretics: Courts, State Authority, and Minority Rights in Pakistan' (2011) <http://web.law.columbia.edu/sites/default/files/ microsites/lawculture/files/2011-files/Nation\%26 Heretics_SAEED.pdf $>$.

Shankar, S. (2009). Scaling Justice: India's Supreme Court, Anti-Terror Laws, and Social Rights. Oxford, England: Oxford University Press.

Shapiro, M.M. (1986). Courts, a Comparative and Political Analysis. Chicago, IL: University of Chicago Press.

Sullivan, W. (2005). The Impossibility of Religious Freedom. Princeton, NJ: Princeton University Press.

Talreja, K.M. (1996). Historic quotes of Guruji M.S. Golwalkar. New Delhi, India: Rashtriya Chetana Prakashan.

Tilly, C. (2006). Why? What happens when people give reasons and why. Princeton, NJ: Princeton University Press.

United Nations General Assembly, Human Rights Council. (2013). Report of the Special Rapporteur on Freedom of Religion or Belief, Heiner Bielefeldt. 26 December 2013.

\footnotetext{
${ }^{1}$ This short quote does not, of course, capture the full sophistication and complexity of Bielefeldt's thinking on the matter, only his general attitudes towards the beneficial potentials of law. In his broader address, for example, Bielefeldt explains that religious tensions should not be understood simply as "natural phenomenon," but rather as the product of identity politics and other political dynamics. Accordingly, in this framing of things, the ameliorative effects of courts stem in large part from their rising above politics, rather than being enmeshed in politics.

${ }^{2}$ Advocates of a strong version of liberalism that favors individual rights over group rights might point out that separate personal law regimes exist for different religious communities in all four of the jurisdictions that we discuss. They might, therefore, point to the prevalence of group rights as the source of polarization. While personal law systems play some role in some of the cases, the mechanisms and dynamics that we describe are not peculiar to or derivative from jurisdictions that protect group rights. Rather these dynamics may equally be seen in places without such protections. For example, one can see similar dynamics at play in the context of the United States (Sullivan, 2005).

${ }^{3}$ For more detailed analysis of these dynamics in the Sri Lankan case, see Schonthal (2014).

${ }^{4}$ This bill was never taken up by parliament.

${ }^{5}$ Interview with leader in Methodist church, May 6, 2009.

${ }^{6}$ Article 121(1) of Sri Lanka's constitution permits any citizen or group (provided three-fourths of the group's registered members are Sri Lankan citizens) to challenge the constitutionality of a bill before the Supreme Court within a week of the bill being placed on the Order Paper of Parliament.

${ }^{7}$ Interview with member of committee, May 17, 2009.

${ }^{8}$ See Moustafa (2014).

${ }^{9}$ Hindu Right is the term used to characterize the Hindu social, religious, and political organizations that cluster under the umbrella of Sangh Parivar. The Bharatiya Janata Party is part of this group.

${ }^{10}$ The Orissa High Court found oppositely to the Madhya Pradesh High Court. In Orissa, the court held the Act ultra vires partly finding with the party who opposed the act, on the grounds that the
} 
definition of “inducement” was indeed too vague and, as such, would prohibit too many proselytizing activities.

${ }^{11}$ Previous anti-conversion bills in parliament, that were proposed and withdrawn, include the Indian Converts Regulation and Registration Bill (1955) and a similar Bill in 1960.

${ }^{12}$ The Pakistan case (below) describes another case of influential public protest. In India, Christian protestors sought to expand the space for conversion-focused activities and, thus, shifting religious identities; however, in Pakistan, protestors sought to restrict the scope for movement away from staterecognised forms of Islam.

${ }^{13}$ Other judgments have exacerbated religious tensions. A judgment in the Shah Bano case, which involved a Muslim woman's claim to maintenance from her divorced husband, was upheld over the objection that to do so would undermine Muslim personal law. This important decision precipitated a series of political actions - including the Government's support of legislation to undo the decision. The case became a rallying cry for many, who 7 years later participated in the destruction of the Babri Masjid mosque in the city of Ayodhya. The Chief Justice's remarks about Islam in that judgment triggered a cry that the judges were Islamophobic. Cossman and Kapur (1996, 2001) argue that the court did not stop to consider that this uniform "way of life" is one based on assimilating religious and cultural minorities and on reconstituting all Indian citizens in the image of the unstated dominant norm, that is, a Hindu norm. See also Nussbaum(1999).

${ }^{14}$ Research on judicial behaviour in 190 anti-terror cases indicates that on the contrary, judges are more likely to rule in favour of Muslim (and Sikh) minorities as long as they do not harbour secessionist impulses (Shankar, 2009) .

${ }^{15}$ I used an online legal database, Manupatra, to find the cases on religious conversion in the high courts and the Supreme Court from 1950-2006, using a keyword search. Manupatra is a database used by the high court and Supreme court libraries and registrars. Manupatra typically captures 80-90\% of the cases reported in the Supreme Court Recorder. I then used an excel sheet to code the cases according to characteristics such as the type of case, ruling, type of conversion, religious groups involved, SC litigant and others, and used the Stata program to run the regression models. Results are available with the author.

${ }^{16}$ The state is aware of the imbalance. Under V.P. Singh's government (1989-90), the law was amended to extend affirmative action benefits to Hindu SCs converting to Buddhism, but SC Christians and Muslims still remained outside the fold (unless they were included as part of the backward classes in a state). The courts too have issued several judgments that treat affirmative action benefits as accruing to a backward class, rather than a caste. See, for instance, Moazzam Ali, Pradhan v. State of U.P., Writ Petition No. 6152 of 2001, Allahabad High Court.

${ }^{17}$ M.S. Golwalkar quoted in Talreja (1996). The Hindu nationalists have a long association with the issue of religious conversion. As Cassie Adcock (2013) points out, they were among the Indian elites who in the 1920s changed the meaning of shuddi, a lower caste "ritual-political" struggle for dignity with the upper castes, into the language of religious freedom and whether it should protect

proselytizing, or whether proselytizing would be an intolerable threat to peaceable relations between (Hindu and Muslim) religious groups. This meaning continues to pervade the discourse on religious conversion.

${ }^{18}$ See Shankar, S. "Secularity and Hinduism’s Imaginaries in India” in M. Kunkler, J. Madeley \& S. Shankar (Eds.), A Secular Age Beyond the North Atlantic (under review, Cambridge University Press). ${ }^{19}$ See the contrasting judgments of Bommai v. Union of India, 1994 SC 1918 and Manohar Joshi $v$. Nitin Bhaurau Patil, 1996, 1 SCC.

${ }^{20}$ Interview with S. Gurumurthy, an ideologue of the RSS and a co-convenor of the Swadeshi Jagran Manch, an organization for promoting the awareness of Indian tradition (March 6, 2007, Chennai, India).

${ }^{21}$ As previously noted, an expansive argument concerning the interface of constitutionalism and increased religiosity worldwide is Hirschl (2010). For an example of this framing in relation to Malaysia specifically, see Liow (2009).

${ }^{22}$ Lina Joy v. Majlis Agama Islam Wilayah Persekutuan dan lain lain [2007] 4 M.L.J. 585, Lina Joy v. Majlis Agama Islam Wilayah \& Anor, [2004] 2 M.L.J. 119.

${ }^{23}$ Article 11 Coalition, http://www.article11.org/ (last visited March 2, 2010). The website has since been closed.

${ }^{24}$ Press Release, PEMBELA, "Pertubuhan-Pertubuhan Pembela Islam Desak Masalah Murtad Ditangani Secara Serius” (Defenders of Islam Urge More Seriousness in Handling the Apostasy Problem; July 17, 2006; on file with the authors).

${ }^{25}$ For a more detailed examination of these mobilization dynamics, see Moustafa (2013). 


\footnotetext{
${ }^{26}$ For contextual details on how and why these cases became the sudden focus of media attention and civil society mobilization, see Moustafa (2013). Briefly, they are (a) a swiftly changing media environment with the rapid proliferation of digital media outlets; (b) the increased capacity and boldness of civil society organizations in the "reformasi" era; (c) the eruption in 2001 of an "Islamic state debate" between the ruling United Malays National Organisation and the opposition Islamist party, Parti Islam se-Malaysia; and (d) the strategic decision of liberal rights groups to "go public" about the difficulties that some non-Muslims were experiencing as a result of the contested jurisdiction of the shariah courts.

${ }^{27}$ A statutory declaration is the equivalent of an affidavit. A deed poll is a legal statement to express an intention.

${ }^{28}$ Attorneys recounted that shariah court judges had regularly facilitated the official recognition of conversion out of Islam when they were called on. Interviews with Latheefa Koya and Fadiah Nadwa Fikri, attorneys in Kuala Lumpur, Malaysia (June 29, 2009).

${ }^{29}$ Similar patterns are highlighted by Andreas Wimmer, Ethnic Boundary Making: Institutions, Power, Networks (Oxford: Oxford University Press, 2013).

${ }^{30}$ In Pakistan, questions about religious freedom and the Ahmadis involve several constitutional provisions. These include provisions regarding (a) freedom of religious belief and practice ("subject to public order"); (b) a prohibition on legislation considered "repugnant to Islam"; (c) "the legislative primacy of parliament" (in light of "advice" from a special council charged with assessing matters of repugnancy); (c) the formation of a Federal Shariat Court (1980) to determine whether laws are "repugnant to Islam"; and (e) ongoing debates about the extent to which, via constitutional amendments or routine legislation, parliament or the executive can make laws (including emergency laws) that do not merely regulate but substantively annihilate fundamental religious rights. See Nelson (2015).
} 